Potravinarstvo Slovak Journal of Food Sciences vol. 15, 2021, p. 460-466

https://doi.org/10.5219/1544

Received: 16 January 2021. Accepted: 15 April 2021.

Available online: 28 May 2021 at www.potravinarstvo.com

(C) 2021 Potravinarstvo Slovak Journal of Food Sciences, License: CC BY 4.0

ISSN 1337-0960 (online)

\title{
POTENTIAL PROBIOTIC YEAST ISOLATED FROM AN INDONESIAN INDIGENOUS FERMENTED FISH (IKAN BUDU)
}

\author{
Yetti Marlida, Nurul Huda, Harnentis, Yuliaty Shafan Nur, Nuri Mekar Lestari, \\ Frederick Adzitey, Mohd Rosni Sulaiman
}

\begin{abstract}
Budu is a fermented food resulting from the activities of microorganisms like lactic acid bacteria and yeast. Budu, therefore, serves as a source of probiotics that can have beneficial effects on livestock and humans. Nonetheless, their selection has to be done with caution. The current study purposed to find out whether budu has desirable probiotic properties. This was done by determining its $\mathrm{pH}$, bile acid tolerance, hydrophobicity, and inhibition of pathogens such as Staphylococcus aureus, Salmonella enteritidis, and Escherichia coli. An in vitro experiment was conducted using three Saccharomyces cerevisiae (coded as SC 11, SC 12, and SC 21) in the preparation of budu. The whole experiment was repeated four times. The budus were tested for their probiotic properties (low $\mathrm{pH}$, bile salts, hydrophobicity, and inhibition of pathogenic bacteria). The results showed that the three Saccharomyces cerevisiae survived in gastric juice and bile acid, exhibited good hydrophobicity, and could inhibit pathogenic bacteria, both gram-positive and negative pathogens. They were able to survive at $\mathrm{pH} 2$ for $3 \mathrm{~h}$ ( 40.70 to $55.1 \%$ ), at $\mathrm{pH} 2$ for $5 \mathrm{~h}$ ( 35.25 to $46.88 \%$ ), in $0.3 \%$ bile acid incubated for $3 \mathrm{~h}(69.69$ to $86.56 \%$ ), in $0.3 \%$ bile acid incubated for $5 \mathrm{~h}(82.22$ to $88.18 \%)$ and hydrophobicity ability of 97.0 to $98.1 \%$. The inhibition activity against pathogenic bacteria, that is, Escherichia coli was 2.50 to $3.81 \mathrm{~mm}$, Staphylococcus aureus was 1.66 to $3.71 \mathrm{~mm}$, and Salmonella enteritidis was 1.20 to $2.64 \mathrm{~mm}$.
\end{abstract}

Keywords: probiotic properties; inhibition of pathogenic bacteria; Indonesian fermented fish; Ikan Budu; poultry infection

\section{INTRODUCTION}

In recent times, the use of antibiotic growth promoters (AGP) in livestock business or broiler business, in particular, has been banned. This is due to consumer concerns about the presence of AGP residues in products such as meat, milk, and eggs, because of the potential risk of drug resistance they pose to humans. Farmers always try to find a substitute for AGP with organic compounds such as plant extracts, prebiotics in the form of MOS (mannan oligosaccharides) and FOS (fructooligosaccharides), and probiotics such as giving live microorganisms to livestock (Davari et al., 2019). Microorganisms of the lactobacillus genera are mostly used for the commercial production of probiotics, especially in fermented milk worldwide (Sharif et al., 2017). Probiotics promote the growth of healthy microflora in the gastrointestinal tract (Rajoka et al., 2018).

Probiotics can be from bacteria, fungi, and yeast. Bacteria that are widely used as probiotics are lactic acid bacteria, from fungi are Rhizopus oligosporus, while from yeast are Saccharomyces cerevisiae and Saccharomyces boulardii. The source of microorganisms used as probiotics is essential, which is usually obtained from the digestive tract of livestock because they are already adapted to the intestine. There are not many reports showing that probiotics are isolated from fermented foods such as budu.

Traditional fermented fish, also known as budu is produced mainly in West Sumatra, Indonesia. Budu is usually made from leather skin (Chorinemus spp.) and Spanish mackerel (Scomberomorus spp.) known as Ikan Talangand Ikan Tenggiri, respectively, in the Indonesian language (Huda, 2012). Budu processing starts with the hanging of fresh fish by the tail fin for four hours under room temperature. It is then eviscerated, washed, and covered with a layer of salt in a traditional container. After which, it is stored for one day at room temperature and sundried for five days. Garlic and white pepper can be sprinkled on the fish during the drying process to improve the quality of the budu (Huda and Ahmad, 2006).

Anggraini et al. (2019) isolated lactic acid bacteria from budu and found that the LAB produced Gammaaminobutyric acid (GABA), which served as anti-heat stress for broilers. They also found that yeast undergoes symbiosis with lactic acid bacteria in budu. Stadie et al. (2013) reported a symbiotic relationship between yeast and lactic acid bacteria of water kefir origin. Symbiosis 
(commensalism or mutualism) widely occurs in fermented foods such as sourdough, milk kefir, and yogurt.

As a probiotic, yeast must be able to withstand gastric $\mathrm{pH}$, bile acids, and pathogenic bacteria. Brandão et al. (2014) found that acidic $\mathrm{pH}$ was not affected by the fatty acid composition of $S$. boulardii. Yeast is capable of maintaining its internal $\mathrm{pH}$ by consuming $\mathrm{H}+$ through a metabolic pathway and by using cell buffer systems. Ogunremi et al. (2015) added that Pichia kudriavzevii ROM 11, that is, yeast from Ogi, which is a cereal pudding fermented food from Nigeria usually made from corn, sorghum, or millet, had a resistance of $86.36 \%$ against bile acids with a concentration of $0.3 \%$.

The purpose of the research was to find yeast present in budu that can serve as a probiotic for potential application for poultry production.

\section{Scientific hypothesis}

As the yeast-derived from fermented foods from West Sumatra such as fermented fish (budu) has not been exploited, especially as a candidate for probiotics, the study hypothesizes that probiotic yeast exists in fermented fish Ikan Budu.

\section{MATERIAL AND METHODOLOGY \\ Samples}

A sample of budu was purchased from a traditional producer at Pariaman Regency, West Sumatra, Indonesia. Budu was made from coral reef fish such as red Kakap (L. campechanus) and Tenggiri fish (Scomberomorini) as shown in Figure 1.

\section{Chemicals}

Chemicals used in this study were $\mathrm{NaCl}$ (Merck, Germany), glycerol (Merck, Germany), HCl (Merck, Germany), oxgall (synthetic bile salts) (Merck, Germany), phosphate buffer (Merck, Germany), and lactic acid (Merck, Germany). The media used in this study were yeast universal agar, nutrient broth, and nutrient agar. All media used were also purchased from Merk, Germany.

\section{Biological Material}

Biological material involved in this study was isolated of Salmonella enteritidis, Staphylococcus aureus, Saccharomyces cerevisiae, and Escherichia coli.

\section{Equipment}

The equipment used in this study were microscope (Merck, Germany) spectrophotometer (Mettler Toledo UV Vis, Inggris), incubator (Thomas Scientific, USA), autoclaved (Systec autoclaved company, Japan), and caliper (Misumi, Indonesia).

\section{Description of Experiments}

Isolation of yeast was conducted according to the method of Bajwa and Sharma (2018). The budu (1 g) was added to $9 \mathrm{~mL}$ of $0.9 \% \mathrm{NaCl}$ (saline) solution and mixed thoroughly for $60 \mathrm{~s}$. Serial dilution was then carried out in saline solution and spread plated onto yeast universal agar. The yeast universal agar was composed of 3.0 g.L.-1 malt extract, 3.0 g.L $\mathrm{L}^{-1}$ yeast extract, 10.0 g.L $\mathrm{L}^{-1}$ glucose, 5.0 g.L $\mathrm{L}^{-1}$ peptone, and 15.0 g.L. $\mathrm{L}^{-1}$ agar. The spread plated yeast universal agar was incubated for $72 \mathrm{~h}$ at $28^{\circ} \mathrm{C}$. Presumptive yeast showed white-to-yellow colonies under the microscope. Such isolates were randomly selected and further purified on yeast universal agar. Yeasts showing the typical appearance of Saccharomyces (white-to-yellow colonies) were selected. The selected yeast strains were further purified by successive streaking on yeast universal media. Three isolates were maintained at $-80{ }^{\circ} \mathrm{C}$ in $20 \%$ (v/v) glycerol (Hi-Media).

$\mathrm{pH}$ resistivity test was done using a modified nutrient broth in which $0.1 \mathrm{~N} \mathrm{HCl}$ was added to achieve a $\mathrm{pH}$ of 2 which corresponds with gastric $\mathrm{pH}$ as described by Ogunremi et al. (2015). The yeast extract $(1 \mathrm{~mL})$ was inoculated in modified $\mathrm{HCl}$ nutrient broth and incubated at $37^{\circ} \mathrm{C}$ for 3 and $5 \mathrm{~h}$. After which, the absorbance was read at a wavelength of $600 \mathrm{~nm}$. This research was conducted with three replications. Isolates resistance was also expressed as a percentage, according to Ogunremi et al. (2015).

Bile salt resistivity test was conducted using mixed modified $\mathrm{HCl}$ nutrient broth with $0.3 \%$ oxygall (synthetic bile salts) and incubated for 3 and 5 h (Ogunremi et al., 2015). The culture was streaked onto a modified nutrient broth and incubated at $37{ }^{\circ} \mathrm{C}$. $1 \mathrm{~mL}$ of yeast isolate was streaked onto the bile salt modified nutrient broth medium. Incubation was done at $37^{\circ} \mathrm{C}$ (Ogunremi et al., 2015). The results were obtained qualitatively by comparison of the yeast absorbancy of the control (not streaked with yeast) with the streaked modified nutrient broth $(0.3 \%$ bile salts).

Hydrophobicity test or attachment was carried out by the method of Vinderola et al. (2004) using stainless steel plates. Clean and dried stainless-steel plates were marked on one side. One hundred (100) $\mathrm{mL}$ of distilled water was used to dissolve $0.8 \mathrm{~g}$ of nutrient broth. Growth media and stainless steel were autoclaved at $121{ }^{\circ} \mathrm{C}$ for $15 \mathrm{~min}$.

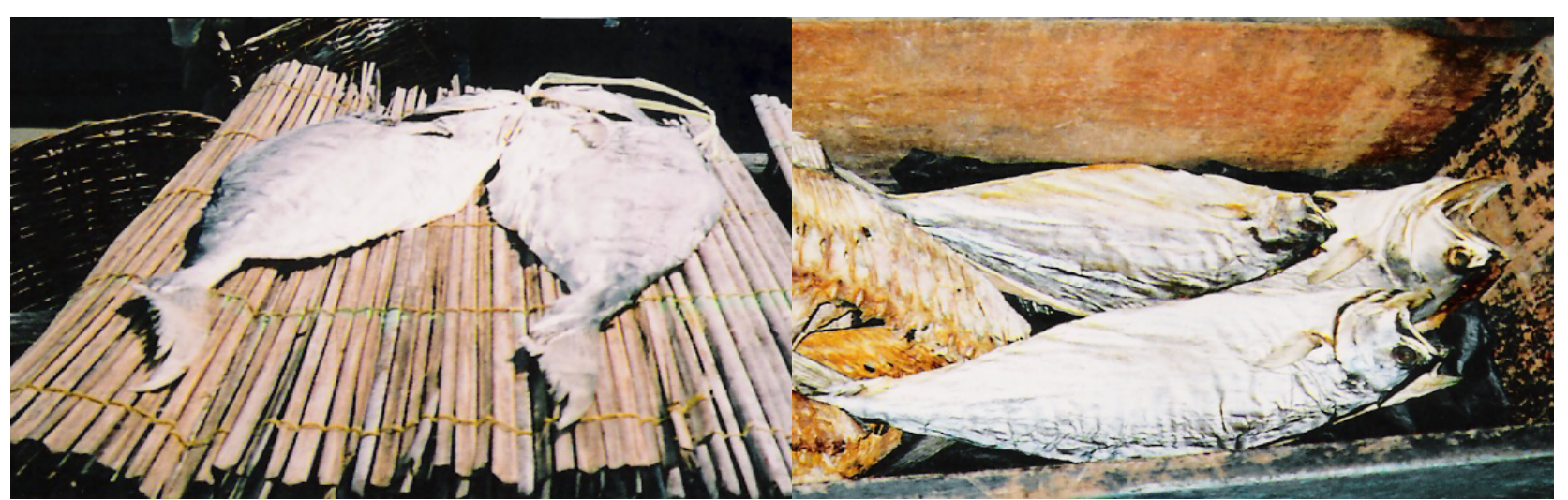

Figure 1 Fermented fish (budu) made from Tenggiri fish (Scomberomorini). 
The stainless steel plate was placed in $25 \mathrm{~mL}$ nutrient broth inoculated with $1 \mathrm{~mL}$ of LAB in an Erlenmeyer and incubated for $24 \mathrm{~h}$ at $29{ }^{\circ} \mathrm{C}$. Furthermore, the surface of the stainless steel was evenly wiped with a swab. The swab was put in a tube containing $10 \mathrm{~mL}$ of phosphate buffer and homogenized. It was then measured by looking at the absorbance at a wavelength of $600 \mathrm{~nm}(\mathrm{~A})$. To measure the growth in the liquid phase, $1 \mathrm{~mL}$ of liquid was taken from nutrient broth media and diluted in $9 \mathrm{~mL}$ of phosphate buffer solution. After which, it was measured at a wavelength of $600 \mathrm{~nm}$ (Ao). The percentage hydrophobicity was calculated using the formula of Fadda et al. (2017).

The antimicrobial activity test of 3 yeast isolates against Salmonella enteritidis, Staphylococcus aureus, and Escherichia coli was carried out based on a modification from Diosma et al. (2013). Nutrient agar (10 grams) was added to $500 \mathrm{~mL}$ of distilled water, homogenized, heated in a water bath, and autoclaved. The media was allowed to cool $\left( \pm 45^{\circ} \mathrm{C}\right)$, and $0.2 \%$ of test bacteria was added into $\pm 10 \mathrm{~mL}$ Petri dishes and allowed to solidify. Meanwhile, a blank antibiotic disk was soaked in the lactic acid bacteria solution for approximately $10 \mathrm{~min}$ and was placed on the surface of the nutrient agar medium containing the pathogenic bacterial isolates. It was then incubated aerobically at $37^{\circ} \mathrm{C}$ for $24 \mathrm{~h}$. After incubation, the diameter of the inhibition zones was measured using a caliper.

\section{Statistical Analysis}

Data were subjected to a one-way analysis of variance (ANOVA), and Tukey's test was used for comparison of means using SPSS version 20.0 Software (SPSS Inc., Chicago, IL, USA). A significant difference was defined at $p<0.05$.

\section{RESULTS AND DISCUSSION}

\section{Resistance test of yeast isolates to gastric $\mathrm{pH}$}

The resistance of yeast to gastric $\mathrm{pH}$ was tested at $\mathrm{pH} 2$ because the $\mathrm{pH}$ in the proventriculus and gizzard is $2.0-3.5$ (Rougie're and Carre, 2010). The gastric $\mathrm{pH}$ was tested for $3 \mathrm{~h}$ and $5 \mathrm{~h}$, the results for which can be seen in Table 1 . The results of the study showed that all yeast isolates could survive at $\mathrm{pH} 2$ with resistance $>30 \%$. The resistance of the yeast isolates to $\mathrm{pH}$ did not differ significantly $(p>0.05)$ from each other. The three yeast isolates of budu origin grew at $\mathrm{pH} 2$ with the viability of $55.1 \%$ for isolate SC 11 , $43.70 \%$ for isolate SC 12 , and $40.70 \%$ for isolate SC 21 , which were incubated for $3 \mathrm{~h}$. When the time incubation time was increased to $5 \mathrm{~h}$, the percentage viability decreased.

The $\mathrm{pH}$ of $2.0-3.5$ is $\mathrm{pH}$ in the proventriculus, where $\mathrm{HCl}$ is produced. The probiotic yeast work in the gastrointestinal tract (GIT) by providing nutrients that aid in the digestion of food and inhibition of harmful bacteria. Probiotics are also mixed or added to feed to increase the rate of feed and nutrient utilization (Markowiak and Śliżewska, 2018).

The results in Table 1 show that the yeast isolate that had the highest resistance to gastric juice was SC 11, with resistance $>50 \%$. Nurnaafi, Setyaningsih and Desniar (2015) explained that good probiotic isolates are those with a survival rate of more than $50 \%$ under low $\mathrm{pH}$ conditions and are resistant to bile salts. The resistance of isolate SC
11 at $3 \mathrm{~h}$ incubation time was $55.10 \%$ and decreased at $5 \mathrm{~h}$ incubation time to $46.88 \%$, a difference of $8.22 \%$. The results of this study were similar to those of Kumura et al. (2004), who found that yeast (Kluyveromyces lactis S25) isolated from commercial blue cheese and kefir had a resistance of $54.7 \%$. The results of this study for SC 11 were higher than those of Diosma et al. (2013). They examined yeast isolates from kefir (tested at $\mathrm{pH} 2.5$ with an incubation time of 3 hours) and reported that Kluyveromyces marxianus 8116 had $45.5 \%$ resistance, Saccharomyces cerevisiae 8115 had $40.5 \%$ resistance, and Saccharomyces boulardii had $45.5 \%$ resistance.

Tovar et al. (2002) reported that when yeast isolates enter the digestive tract of poultry, they must be able to survive at low $\mathrm{pH}$ because the proventriculus and gizzard have a $\mathrm{pH}$ of $2.0-4.5$. Zubaidy and Khanda (2014) added that Saccharomyces cerevisiae var boulardii (S.b32) was able to survive at low $\mathrm{pH}$. Glucomannan, chitin, mannoprotein, and beta-glucan make up the cell component of Candida sp. Drabikova et al. (2009). However, beta-glucan forms the largest $(50-60 \%)$ component of the inner layer of the cell wall, while chitin forms $1-10 \%$. Mannoproteins form mainly $30-40 \%$ of the outer layer of the cell wall. They play a major role in interactions with the host, determine the nature of the cell surface and cell-to-cell recognition (Vickova et al., 2004).

\section{Resistance test of yeast isolates to bile salts}

Resistance of the yeast isolates to bile salt was not significantly different $(p>0.05)$. The results in Table 1 shows that isolate SC 11 had a resistance ability of $69.69 \%$ at an incubation time of 3 hours and increased to $82.02 \%$ at an incubation time of 5 hours, a difference of $12.33 \%$ increase. The results of this study are comparable to those of Chen et al. (2010), who examined yeast isolated from fresh milk on Beijing and Heilongjiang farms against $0.3 \%$ bile salts and reported that Pichia fermentans HJ15 isolate had $79 \%$ resistance, Pichia kudriavzevii BY10 isolate had a resistance of $25.9 \%$, and Yarrowia lipolytica HJ6 isolate had a resistance of $62.9 \%$.

Yeast can survive in bile salt solutions because of its extreme environmental resistance (Chen et al., 2010). Chen et al. (2010) explained that yeast develops resistance properties in stressful environments (salt, acids, and sugars), and in competition with other microbial yeasts, they can live a normal life. The difference in the results of this study can be due to the differences in the type of yeast tested against $0.3 \%$ bile salts. Yeast cell walls are mostly composed of beta-glucan (Lee et al., 2001). Ooi and Liu (2000) reported that beta-glucan is a linear polysaccharide that contains monomers of glucose that are linked by glycosidic bonds. Beta-glucan is water-soluble, and a small concentration will produce high viscosity (Suzuki et al., 2001) and will form a gel in the digestive tract to increase the excretion of bile acids. By this, the fat is not emulsified and absorbed in the stomach. 


\section{Inhibition test against pathogenic bacteria}

The ability of yeast to act antagonistically is due to changes in medium $\mathrm{pH}$, competition for nutrients, secretion of antimicrobial agents, and production of ethanol in high concentrations. Staphylococcus aureus, Escherichia coli, and Salmonella enteritidis were chosen because they are among the pathogenic bacteria associated with poultry and other animals. The results of the study (Table 2)showed that the inhibitory zone produced by isolate SC 11 against Escherichia coli was $3.81 \mathrm{~mm}$, and greater than the inhibition zone of $3.71 \mathrm{~mm}$ produced against Staphylococcus aureus. However, the inhibition of the yeast isolates to Staphylococcus aureus, and Escherichia coli did not differ significantly $(p>0.05)$. The differences in the bacterial cell walls could not cause significant differences in their resistance to yeast. Staphylococcus aureus is grampositive bacteria, while Escherichia coli is gram-negative bacteria. Saidi et al. (2019) reported that gram-negative bacteria have a thinner layer of peptidoglycan $(5-10 \mathrm{~cm})$, while gram-positive bacteria have a thicker layer of peptidoglycan $(20-80 \mathrm{~cm})$. Therefore, it was more difficult for yeast isolates to penetrate the cell wall of Staphylococcus aureus bacteria than the cell wall of Escherichia coli bacteria.

Table 2 shows that the inhibition of Salmonella enteritidis by yeast was numerically lower than that of Staphylococcus aureus and Escherichia coli. This might be influenced by antigens present in Salmonella. According to Wang et al. (2020), Salmonella has three main antigens, namely: somatic antigens or $\mathrm{O}$ antigens, flagellate antigens or
$\mathrm{H}$ antigens, and capsule antigens or $\mathrm{Vi}$ antigens; which produce enterotoxins and cytotoxins, making it difficult for yeast to inhibit their growth.

The inhibitory strength possessed by yeast varies; therefore, different yeast species will produce different inhibition and metabolite activities during fermentation. Freimoser et al. (2019) studied the antagonistic activity of Kloeckera and Kluyveromyces species against bacteria and found that they produce intracellular and extracellular antimicrobial compounds that inhibit the growth of gramnegative and gram-positive bacteria. Research by Suzuki et al. (2001) and Marquina et al. (2002) found yeast to produce antagonistic activity due to the production of killer toxins or mycotoxins. These toxins are extracellular proteins or glycoproteins that can damage the cell membrane. The antimicrobial activity of yeast through the secretion of organic acids and antimicrobial peptides has been reported (Boirivant and Strober, 2007; Vanderpool, Yan and Polk, 2008; Ciorba, 2012). $S$. boulardii secretes mainly capric acid, a medium-chain fatty acid which showed bioactivity against Candida albicans and formation of biofilms (Krasowska et al., 2009; Murzyn et al., 2010). S. cerevisiae secretes antimicrobial peptides (saccharomycin), which inhibits the growth of pathogenic bacteria (Hammami et al., 2013). Antimicrobial peptides inhibit bacteria growth by absorbing the cell membrane receptors, destructing cell membrane permeability and alteration of intracellular $\mathrm{pH}$ (Rizk et al., 2018).

Table 1 The resistance of yeast isolates towards acid and bile salt conditions.

\begin{tabular}{lll}
\hline \multicolumn{1}{c}{ Isolates yeast } & Time $\mathbf{( 3 ~ h ) ( \% )}$ & Time (5 h)(\%) \\
\hline Acid condition & & \\
\hline Saccharomyces cerevisiae (SC) 11 & $55.10 \pm 2.19$ & $46.88 \pm 1.82$ \\
Saccharomyces cerevisiae (SC) 12 & $43.70 \pm 1.35$ & $39.36 \pm 0.80$ \\
Saccharomyces cerevisiae(SC) 21 & $40.70 \pm 0.87$ & $35.26 \pm 0.38$ \\
\hline Bile salt condition & & \\
\hline Saccharomyces cerevisiae(SC) 11 & $69.69 \pm 0.14$ & $82.02 \pm 0.53$ \\
Saccharomyces cerevisiae(SC) 12 & $84.54 \pm 1.37$ & $87.43 \pm 1.91$ \\
Saccharomyces cerevisiae(SC) 21 & $86.56 \pm 1.71$ & $88.18 \pm 1.72$ \\
\hline
\end{tabular}

Note: values were reported as means $\pm S D$ of triplicate groups.

Table 2 The resistance of yeast isolates towards pathogenic bacteriaassociated with poultry.

\begin{tabular}{cccc}
\hline \multirow{2}{*}{ Yeast isolates } & \multicolumn{3}{c}{ Diameter inhibition zone (mm) } \\
\cline { 2 - 4 } & Escherichia coli & Staphylococcus aureus & Salmonella enteritidis \\
\hline Saccharomyces cerevisiae (SC) 11 & 3.81 & 3.71 & 2.64 \\
Saccharomyces cerevisiae (SC) 12 & 2.50 & 2.56 & 2.52 \\
Saccharomyces cerevisiae(SC) 21 & 1.63 & 1.66 & 1.20 \\
\hline
\end{tabular}

Note: values were reported as means $\pm S D$ of triplicate groups; mean values in the same column with different lowercase were significantly different $(p<0.05)$.

Table 3 The hydrophobicityof yeast on stainless steel plates.

\begin{tabular}{cc}
\hline Yeast Isolates & Hdrophobicity (\%) \\
\hline Saccharomyces cerevisiae (SC) 11 & $97.00 \pm 0.24$ \\
Saccharomyces cerevisiae (SC) 12 & $97.96 \pm 0.72$ \\
Saccharomyces cerevisiae (SC) 21 & $98.71 \pm 0.19$ \\
\hline
\end{tabular}

Note: values were reported as means $\pm S D$ of triplicate groups. 


\section{Hydrophobicity using stainless steel plates}

Table 3 shows the hydrophobicity of the yeast isolates. From Table 3, all the yeast isolates had a hydrophobicity percentage $>90 \%$. The hydrophobicity of yeast isolates was not significantly different $(p>0.05)$.

The results of this study were higher than those of Sourabh et al. (2011), who showed that Saccharomyces cerevisiae isolated from traditional West Himalayan fermentation food, $\mathrm{Sc} 01$ had a hydrophobicity percentage of $59.65 \%$. Fadda et al. (2017) found that Saccharomyces boulardii isolated from codex had a hydrophobicity ability of $55.9 \%$, Kluyveromyces lactis isolated from kefir had a hydrophobicity ability of $74.1-79.4 \%$ and Kluyveromyces marxianus had a hydrophobicity ability of $75.9 \%$.

The ability of microorganisms to attach to the digestive tract becomes one of the selection criteria for probiotics. The formation of colonies in the digestive tract is influenced by the ability of microorganisms to attach to the digestive tract that is specific to the host (Suzuki et al., 2001). Tovar et al. (2002) reported that some yeast species can synthesize and secrete polyamine molecules which can stimulate the development of the digestive tract and the production of digestive enzymes.

\section{CONCLUSIONS}

The results indicated that all the isolates identified were Saccharomyces sp., (SC 11; SC 12 and SC 21) and showed notable potential probiotic properties. They exhibited a better survival in gastric juice and bile acid, showed high hydrophobicity, and the ability to inhibit pathogenic bacteria (gram-positive and negative pathogens) associated with poultry. They were able to live at $\mathrm{pH} 2$ for $3 \mathrm{~h}(40.70$ to $55.1 \%), \mathrm{pH} 2$ at $5 \mathrm{~h}(35.25$ to $46.88 \%)$, in bile acid $0.3 \%$ incubated for $3 \mathrm{~h}(69.69$ to $86.56 \%)$, and at $5 \mathrm{~h}(82.22$ to $88.18 \%$ ), and hydrophobicity ability of 97.0 to $98.1 \%$. The inhibition zones produced by Saccharomyces sp. against Escherichia coli was 2.50 to $3.81 \mathrm{~mm}$, Staphylococcus aureus was 1.66 to $3.71 \mathrm{~mm}$, and Salmonella enteritidis was 1.20 to $2.64 \mathrm{~mm}$.

\section{REFERENCES}

Anggraini, L., Marlida, Y., Wizna, W., Jamsari, J., Mirzah, M., Adzitey, F., Huda, N. 2019. Molecular identification and phylogenetic analysis of gaba-producing lactic acid bacteria isolated from indigenous dadih of West Sumatera, Indonesia. F1000 research, vol. 7, p. 1663. https://doi.org/10.12688/f1000research.16224.3

Bajwa, J., Sharma, N. 2018. Evaluation of probiotic properties of yeasts isolated from sidra - an ethnic fermented fish product of North East India. International Journal of Current Microbiology and Applied Sciences, vol. 7, no. 2, p. 2632-2643. https://doi.org/10.20546/ijcmas.2018.702.320

Boirivant, M., Strober, W. 2007. The mechanism of action of probiotics. Current Opinion in Gastroenterology, vol. 23, p. 679-692. https://doi.org/10.1097/MOG.0b013e3282f0cffc

Brandão, R. L.,Rosa, J. C. C., Nicoli, J. R., Almeida, M. V. S., Carmo, A. P., Queiros, H. T., Castro, I. M. 2014. Investigating acid stress response in different Saccharomyces strains. Journal of Mycology, vol. 2014, p. 1-9. https://doi.org/10.1155/2014/178274

Chen, L.-S., Ma, Y., Maubois, J.-L., He, S.-H., Chen, L.-J., Li, H.-M. 2010. Screening for the potential probiotic yeast strains from raw milk to assimilate cholesterol. Dairy Science
\& Technology, vol. 90, p. 537-548. https://doi.org/10.1051/dst/2010001

Ciorba, M. A. 2012. A gastroenterologist's guide to probiotics. Clinical Gastroenterology and Hepatology, vol. 10, no. 9, p. 960-968. https://doi.org/10.1016/j.cgh.2012.03.024

Davari, D. D., Negahdaripour, M., Karimzadeh, I., Seifan, M., Mohkam, M., Masoumi, S. J., Berenjian, A., Ghasemi, Y. 2019. Prebiotics: Definition, types, sources, mechanisms, and clinical applications. Foods, vol. 8, no. 92, p.1-27. https://doi.org/10.3390/foods8030092

Diosma, G., Romanin, D. E., Rey-Burusco, M. F., Londero, A., Garrote, G. L. 2013. Yeasts from kefir grains: Isolation, identification, and probiotic characterization. World Journal of Microbiology and Biotechnology, vol. 30, p. 43-53. https://doi.org/10.1007/s11274-013-1419-9

Drabikova, K., Perecko, T., Nosal, R., Bauerova, K., Ponist, S., Mihalova, D., Kogan, G., Jancinova, V. 2009. Glucomannan reduces neutrophil free radical production in vitro and in rats with adjuvant arthritis. Pharmacological Research, vol, 59, no, 6. p. 399-403. https://doi.org/10.1016/j.phrs.2009.02.003

Fadda, M. E., Valentina, M., Maura, D., Maira, B. P., Sofia, C. 2017. In vitro screening of Kluyveromyces strains isolated from fiore sardo cheese for potential use as probiotics. Food Science and Technology, vol. 75, p. 100-106. https://doi.org/10.1016/j.lwt.2016.08.020

Freimoser, F. M., Mejia, M. P. R., Tilocca, R., Migheli, Q. 2019. Biocontrol yeasts: Mechanisms and applications. World Journal of Microbiology and Biotechnology, vol. 35, p. 154. https://doi.org/10.1007/s11274-019-2728-4

Hammami, R., Fernandez, B., Lacroix, C., Fliss, I.2013. Anti-infective properties of bacteriocins: An update. Cellular and Molecular Life Sciences, vol. 70, p. 2947-2967. https://doi.org/10.1007/s00018-012-1202-3

Huda, N. 2012. Indonesian Fermented Fish Products. In Hui, Y. H., Özgül Evranuz, E. Handbook of Animal-Based Fermented Foods and Beverage Technology. $2^{\text {nd }}$ ed. Boca Raton, US : CRC Press, p. 717-737. ISBN9780429107528.

Huda, N., Ahmad, R. 2006. Budu and tukai: endemic fermented fish products from WestSumatra. INFOFISH International, vol. 3, p. 49-51.

Krasowska, A., Murzyn, A., Dyjankiewicz, A., Lukaszewicz, M., Dziadkowiec, D. 2009. The antagonistic effect of Saccharomyces boulardii on Candida albicans filamentation, adhesion and biofilm formation. FEMS Yeast Research, vol. 9. no. 8, p. 1312-1321. https://doi.org/10.1111/j.15671364.2009.00559.x

Kumura, H., Tanoue, Y., Tsukahara, M., Tanaka, T., and Shimazaki, K. 2004. Screening of dairy yeast strains for probiotic applications. Journal. Dairy Science, vol. 87, no. 12, p. 4050-4056. https://doi.org/10.3168/jds.S00220302(04)73546-8

Lee, J. N., Lee, D. Y., In-Hye, J., Gi-Eun, K., Kim, H. N. 2001. Purification of soluble $\beta$-Glucan with immunoenhancing activity from the cell wall of yeast. Biosience Biotechnology and Biochemistry, vol. 65, no. 4, p. 837-841. https://doi.org/10.1271/bbb.65.837

Markowiak, P., Śliżewska, K. 2018. The role of probiotics, prebiotics and synbiotics in animal nutrition. Gut Pathoglogy, vol. 10, p. 21.https://doi.org/10.1186/s13099-018-0250-0

Marquina, D., Santos, A., Peinado, J. M. 2002. Biology of killer yeasts. International Microbiology, vol. 5, p. 65-71. https://doi.org/10.1007/s10123-002-0066-z

Murzyn, A., Krasowska, A., Stefanowicz, P., Dziadkowiec, D., Lukaszewicz, M. 2010. Capric acid secreted by S. boulardii 
inhibits C. albicans filamentous growth, adhesion and biofilm formation. PLoS One, vol. 5, p. e12050. https://doi.org/10.1371/journal.pone.0012050

Nurnaafi, A., Setyaningsih, I., Desniar. 2015. Potensi probiotik bakteri asam laktat asal bekasam ikan nila (Probiotic potential of lactic acid bacteria from bekasan nila fish). Jurnal Teknologi dan Industri Pangan, vol. 26, no. 1, p. 109-114. https://doi.org/10.6066/jtip.2015.26.1.109 (in Indonesian)

Ogunremi, O. R., Sanni, A. I., Agarwal, R. 2015. Probiotic potential of yeasts isolated from some cereal-based Nigeria traditional fermented food products. Journal of Applied Microbiology, vol. 119, no. 3, p. 797-808. https://doi.org/10.1111/jam.12875

Ooi, V. E., Liu, F. 2000. Immunomodulation and anti-cancer activity of polysaccaride protein complexes. Current Medicinal Chemistry, vol. 7, no. 7, p. 715-729. https://doi.org/10.2174/0929867003374705

Rajoka, M. Sh. R., Hayat, H. F., Sarwar, S., Mehwish, H. M., Ahmad, F., Hussain, N., Shah, S. Z. H., Khurshid, M., Siddiqu, M., Shi, J. 2018. Isolation and evaluation of probiotic potential of lactic acid bacteria isolated from poultry intestine. Microbiology, vol. 87, no. 1, p. 116-126. https://doi.org/10.1134/S0026261718010150

Rizk, Z., El Rayess, Y., Ghanem, C., Mathieu, F., Taillandier, P., Nehme, N. 2018. Identification of multiple-derived peptides produced by Saccharomyces cerevisiae involved in malolactic fermentation inhibition. FEMS Yeast Research, vol. 18, no. 7. p. foy080. https://doi.org/10.1093/femsyr/foy080

Rougie're, N., Carre, B. 2010. Comparison of gastrointestinal transit times between chickens from D1 and D2 genetic lines selected for divergent digestion efficiency. Animal \& The Animal Consortium, vol. 4, no. 11, p. 18611872. https://doi.org/10.1017/S1751731110001266

Saidi, N., Owlia, P., Mahmoud, S., Marashi, A., Saderi, H. 2019. Inhibitory effect of probiotic yeast Saccharomyces cerevisiae on biofilm formation and expression of $\alpha$-hemolysin and enterotoxin A genes of Staphylococcus aureus. Iranian Journal of Microbiology, vol. 11, no. 3, p. 246-254. https://doi.org/10.18502/ijm.v11i3. 1331

Sharif, M., Moridnia, A., Mortazavi, D., Salehi, M., Bagheri, M., Sheikhi, M. 2017. Kefr: a powerful probiotics with anticancer properties. Medical Oncology, vol. 34, p. 183. https://doi.org/10.1007/s12032-017-1044-9

Sourabh, A., Kanwar, S. S., Sharma, O. P. 2011. Screening of indigenous yeast isolates obtained from traditional fermented foods of Western Himalayas for probiotic attributes. Journal of Yeast and Fungal Research, vol. 2, no. 8, p. 117126. https://doi.org/10.5897/JYFR.9000045

Stadie, J., Gulitz, A., Ehrmann, M. A.,Vogel, R. F. 2013. Metabolic activity and symbiotic interactions of lactic acid bacteria and yeasts isolated from water kefir. Food Microbiology, vol. 35, no. 2, p. 92-98. https://doi.org/10.1016/j.fm.2013.03.009

Suzuki, C., Ando, Y., Machida, S. 2001. Interaction of SMKT, a killer toxin produced by Pichia farinosa, with the yeast cell membranes. Yeast, vol. 18, no. 16, p. 1471-1478. https://doi.org/10.1002/yea.791

Tovar, D., Zambonino, J., Cahu, C., Gatesoupe, F. J.,Vazquez-Ju'arez, R., Lesel, R. 2002. Effect of live yeast incorporation in compound diet on digestive enzyme activity in sea bass (Dicentrarchus labrax) larvae. Aquaculture, vol. 204, no. 1-2, p. 113-123. https://doi.org/10.1016/S0044$\underline{8486(01) 00650-0}$

Vanderpool, C., Yan, F., Polk, D. B. 2008. Mechanisms of probiotic action: Implications for therapeutic applications in inflammatory bowel diseases. Inflammatory Bowel Diseases, vol. 14, no. 1, p. 1585-1596. https://doi.org/10.1002/ibd.20525

Vickova, V., Duhova, V., Svidova, S., Farkassova, A., Kamasova, S., Vlcek, D., Kogan, G., Rauko, P., Miadokova, E. 2004. Antigenotoxic potential of glucomannan on four model test systems. Cell Biology and Toxicology, vol. 20, no. 6, p. 325-332. https://doi.org/10.1007/s10565-004-0089-7

Vinderola, C. G., Medici, M., Perdigón, G. 2004. Relationship between interaction sites in the gut, hydrophobicity, mucosal immunomodulating capacities and cell wall protein profiles in indigenous and exogenous bacteria. Journal of Applied Microbiology, vol. 96, no. 2, p. 230-243. https://doi.org/10.1046/j.1365-2672.2004.02158.x

Wang, M., Qazi, I. H., Wang, L., Zhou, G., Han, H. 2020. Review salmonella virulence and immune escape. Microorganisms, vol. 8, no. 407, p. 1-23. https://doi.org/10.3390/microorganisms8030407

Zubaidy, Z. M. A., Khanda, O. K. 2014. Isolation and identification of Saccharomyces cerevisiae var boulardii and its uses as a probiotic (in vitro). Rafidain Journal of Science, vol. 25, no.1, p. 1-11. https://doi.org/10.33899/rjs.2014.86051

\section{Funds:}

The authors are grateful to the Ministry of Research, Technology and Higher Education of Indonesia for funding the BOPTN Andalas University Grants through Research Cluster Grant No: 57/ UN.16.17/HGB/LPPM/2019. Grant for publication fee was by Universiti Malaysia Sabah, Jalan UMS, 88400, Kota Kinabalu, Sabah, Malaysia.

\section{Acknowledgments:}

We would like to thank the University of Andalas, University for Development Studies and Universiti Malaysia Sabah for the support to conduct research in the area of food science and technology.

\section{Conflict of Interest:}

The authors declare no conflict of interest.

\section{Contact Address:}

*Yetti Marlida, University of Andalas, Faculty of Animal Science, Department of Animal Nutrition and Feed Technology, Padang 25163, Indonesia,

E-mail: yettimarlida@ansci.unand.ac.id

ORCID: https://orcid.org/0000-0001-9134-3954

*Nurul Huda, Universiti Malaysia Sabah, Faculty of Food Science and Nutrition, Department of Food Science and Nutrition, 88400, Kota Kinabalu, Sabah, Malaysia; Universitas Sebelas Maret, Faculty of Agriculture, Department of Food Science and Technology, Jln. Ir. Sutami 36 A, Surakarta, Central Java, 57126, Indonesia,

E-mail: drnurulhuda@ums.edu.my

ORCID: https://orcid.org/0000-0001-9867-6401

Harnentis, University of Andalas, Faculty of Animal Science, Department of Animal Nutrition and Feed Technology, Padang 25163, Indonesia,

E-mail: harnentis@ansci.unand.ac.id

ORCID: https://orcid.org/0000-0001-7580-5637

Yuliaty Shafan Nur, University of Andalas, Faculty of Animal Science, Department of Animal Nutrition and Feed Technology, Padang 25163, Indonesia,

E-mail: yuliaty@ansci.unand.ac.id

ORCID: https://orcid.org/0000-0002-4689-9213 
Nuri Mekar Lestari, University of Andalas, Faculty of Animal Science, Department of Animal Nutrition and Feed Technology, Padang 25163, Indonesia,

E-mail: nrlhd usm@yahoo.com.my

ORCID: https://orcid.org/0000-0002-2452-5640

Frederick Adzitey, University for Development Studies, Faculty of Agriculture, Department of Food Science,P.O.

Box TL 1882, Tamale, Ghana,

E-mail: adzitey@yahoo.co.uk

ORCID: https://orcid.org/0000-0002-8814-0272
Mohd Rosni Sulaiman, Universiti Malaysia Sabah, Faculty of Food Science and Nutrition, Department of Food Science and Nutrition, 88400, Kota Kinabalu, Sabah, Malaysia,

E-mail: rossulma@ums.edu.my

ORCID: https://orcid.org/0000-0003-1753-7093

*Corresponding author 